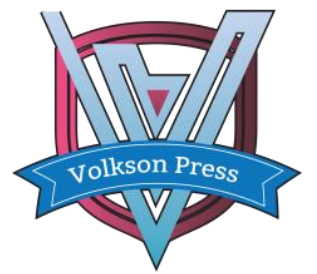

Contents List available at VOLKSON PRESS

Economics \& Management Innovations(EMI)

DOI : http://doi.org/10.26480/icemi.01.2017.188.191

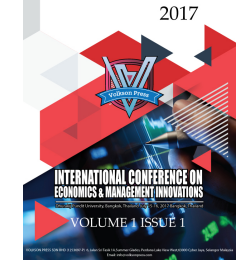

\title{
Students' Perception as a Customer Concept on University Image
}

\author{
Supitcha Cheevapruk ${ }^{{ }^{\prime} 1}$ and Santidhorn Pooripakdee ${ }^{2}$ \\ College of Industrial Technology, King Mongkut's University of Technology North Bangkok ${ }^{1}$, Thailand \\ Faculty of Management Science, Silpakorn University ${ }^{2}$, Thailand supitcha.c@cit.kmutnb.ac.th
}

This is an open access article distributed under the Creative Commons Attribution License, which permits unrestricted use, distribution, and reproduction in any medium, provided the original work is properly cited.

\section{ARTICLE DETAILS}

\section{Article History:}

Received 02 october 2017

Accepted 06 october 2017

Available online 11 october 2017

Keywords:

student's perception, university

image, factor analysis.

\section{ABSTRACT}

Due to the increasing of number of universities in Thailand might lead to high competitive environment. Therefore, the university image and brand play an important role for student's intention to study at each university. This research aims to identify the factors that influence an individual's perception on image and brand at a practice engineering school. The sample group of 420 high school students who applied for technological university was collected. The descriptive statistics and factor analysis were used to examine the students' perception on university image. The results showed that students' perception on image can be categorized into 3 factors: external characteristic factor, emotional factor and taste and intention Factor.

\section{Introduction}

The overview of higher education has been increasingly competitive as the students are also customer (hanover research, 2015). Universities are recently doing more like commercial businesses and assessing their corporate brands and images has become important (Purolinna, 2016). The competition drives the universities to build strongly their image and also focus on their brand (Hemsley - Brown and Goonawardana, 2007). In Higher education sector, the image perceived by stakeholders are important (Helgesen and Nesset, 2007). The students and the parents search for various sources of information in order to choose the suitable university (Moogan,2011). Kardes et al (1993) also mentioned that prospective students may forms brand or image consideration sets for the universities for the most appropriate for them. Universities are able to differentiate themselves by creating strong brand images are recognized by prospective students (Plungpongpan et at, 2016). The uniqueness of higher education is that the university reputation has been traditionally the main indicator together with emergence of branding, the adoption concepts such as brand identity and image are becoming increasingly important (Hemsely - Brown et at, 2016). Due to the increasing of number of universities in Thailand might lead to high competitive environment. Therefore, the university image and brand play an important role for student's intention to study at each university. This research aims to identify the factors that influence an individual's perception on image and brand at a practice engineering school.

\section{Literature Reviews}

There several researches on students' intention to study based on major or specific fields. (Mazzarol and Soutar 2002, Keshishian et. al 2010, Carnasciali and Thomson 2013, Al-Rfou 2013, Tang and Seng 2015 and MacEachern and Yun, 2017) And some study on important factors to attract and retain the students (Helgesen and Nesset 2007, Nguyen and LeBlanc, 2001). For students, the image of an educational institution is important for the realization and decision making of their studies; it gets the loyalty of the students and it is a means to attract other students (Brown and Mazzarol, 2009, Perez and Torres, 2016).

\subsection{University Image}

Barich and Kotler (1991) describes the institutional image as the impression of the public related to various physical and behavioral attributes of the institution. It is also supported by Nguyen and Leblanc (2001) defined university image as the perceived image of the public on university based on their though, idea, interest and also their own personnel experience. The image perception can be incongruent and favorable counteract impression, hence, the harmonization of activities is consequently important. The symbol, value and the building of university image is a length of process that can be improved by technology, sudden achievement or destroyed by neglecting the expectations of the stakeholders (Herbig et. al, 1994). Image sometimes refers to schema. The self- schema (Markus, 1977) refers to a long lasting and stable set of memories that summarize a person's beliefs, experiences and generalizations about the self, in specific behavioral domains. A person may have a self-schema based on any aspect of himself or herself as a person, including physical characteristics, personality traits and interests, as long as they consider that aspect of their self-important to their own self-definition.

\subsection{Student as a Customer Concept}

Lots of universities increased the number admitted as a means of increasing their incomes while admitted students are considered as "customer" (Watjatrakul, 2014). Several universities has adopted many international quality assurance approach such as ABET (Accreditation Board for Engineering and Technology), AUN-QA (ASEAN university network QA) and TQM (total quality management). AUN - QA approach counts students as the key stakeholder whom provide feedback related on their satisfaction based on what university or program provide (ASEAN University Network, 2016). TQM approach has been widely used in business sector in order to improve their business performance and gain more profitability and competitive advantage over the others. These are some example of quality assurance applied in the universities in order to improve their performance and provide better services. Universities are in a competition to attract and retain their students with image, branding and advertisement. The management practice should be considered an organizational image based on consumer orientation. Applying the concept of customers to students might improve educational process, gain more reputation and enhance the students' perception based on the institutional image. A strong image might be easy for the consumer to choose and purchase the product or service which match their need (Hsieh et. al, 2004).

\section{Method and Sampling}


The questionnaires were distributed to the sample group of $420 \mathrm{high}$ school (Mattayom 6) who applied to study at College of Industrial Technology (CIT), King Mongkut's University of Technology North Bangkok. The ransom sampling method was applied and the sample size indicate based on Yamane (1973)

The data presented in this paper were collected through a structured questionnaire. It was designed into 2 parts; the first is demographic data of participants such as gender, education, GPA and intention to study. The second part contained 19 statements measuring students' perception on CIT image which adapted from Saenmueang (2011). The completed data were analyzed using various statistics tools and techniques which were frequency, means and standard deviation and factor analysis in order to determine significant factors on students' perception on image.

The preliminary analysis consists of Cronbach's $\alpha$ was analyzed for reliability analysis. The Cronbach's $\alpha$ coefficient for the total score was 0.909 .The Bartlett's Test of Sphericity and Kaiser- Mayer-Olkin (KMO) Measure of Sampling Adequacy were employed to indicate whether factor analysis is feasible or not. The statistical result of Barlett's and KMO of students' intention and students' adaptation are shown in Table I

\section{Table I KMO and Bartlett's Test}

\begin{tabular}{ll}
\hline Kaiser-Mayer-0lkin & Bartlett's Test of Sphericity \\
Measure of Sampling Adequacy & $\begin{array}{l}\text { Approx. Chl- } \\
\text { Square }\end{array}$
\end{tabular}

The KMO and Bartlett's Test was analyzed to examine the appropriateness of Factor Analysis. The approximate of Chi -square is 3323.552with 171 degrees of freedom which is significant at 0.05 level of significance. The KMO statistic of .915 was also large (greater than 0.60). Hence Factor Analysis is considered feasible.

\section{Finding and Discussion}

\subsection{Descriptive Statistics}

Table II presents the cross-tabulation between respondents' gender and school. The result consisted of 304 males, accounted for 73.6 percent of the total students surveyed, and 109 females, accounted for 26.4 percent of the total students surveyed. The result also shows that the students mostly are from public school.

Table II cross-tabulation between gender and school School

Public Private TechnicalOccupational Total

\begin{tabular}{ccccccc}
\hline Gender & Male & 203 & 34 & 55 & 11 & 303 \\
& Female & 84 & 20 & 3 & 2 & 109 \\
Total & & 287 & 54 & 58 & 13 & 412 \\
\hline
\end{tabular}

The students' perception on image was collected and presented in table III to see the how they think about CIT as a person.

Table III students' perception on image

\begin{tabular}{lcl}
\hline Image & \multicolumn{1}{c}{ Means } & \multicolumn{1}{c}{ S.D. Image } \\
\hline Inert & 3.98 & 0.72 Active \\
\hline Image & Means & S.D.Image \\
\hline Expensive & 3.32 & 0.79Cheap \\
Foolish & 3.98 & 0.83 Clever \\
Indecisive & 4.07 & 0.86 Desicive \\
Rural & 3.85 & 0.92 Urban \\
Simple & 3.18 & 0.84 Luxirious \\
Easy & 3.41 & 0.92 Difficult \\
Childish & 4.01 & 0.80 Adult
\end{tabular}

\begin{tabular}{lll} 
Ancient & 4.02 & 0.87 Modern \\
Old & 3.99 & $0.87 \mathrm{New}$ \\
Wild & 3.69 & $0.91 \mathrm{Mild}$ \\
Rude & 3.77 & 0.89 Polite \\
& & $0.94 \mathrm{Relax}$ \\
Serious & 3.67 & 0.84 Clean \\
Dirty & 3.92 & 0.89 Peaceful \\
Aggressive & 3.87 & 0.94 Unhurried \\
Hurry & 3.60 & $0.82 \mathrm{Happy}$ \\
Unhappy & 4.11 & $0.81 \mathrm{Fast}$ \\
Slow & 3.91 & $1.00 \mathrm{Determined}$ \\
Fun & 3.67 & \\
\hline
\end{tabular}

Table III shows that the average of all items were higher than 2.5 which means the perception of the students tend to be positive as shown in figure 1.

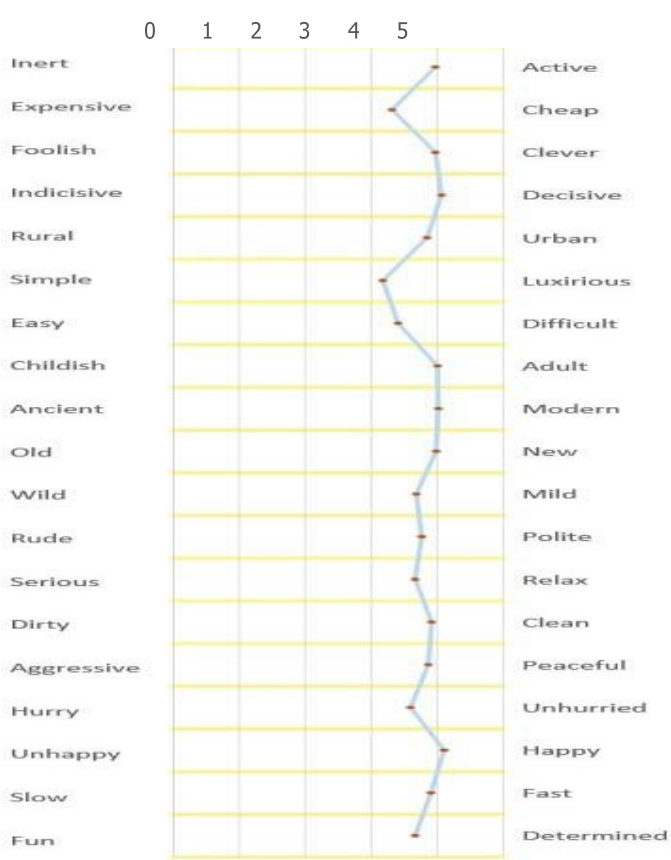

Figure I shows average of all image items

\subsection{Factor Analysis}

Principal component analysis was used to determine and identify students' perception on image. An eigenvalue of 1.0 was used to determine the number of factors with those having a value greater than 1.0 being seen as significant. Table VI present factors extraction with Varimax rotation method on students' intention and students' adaptation respectively.

Table VI present factors extraction

\begin{tabular}{cccc}
\hline Factors & Eigenvalue & \% of Variance & Cumulative \% \\
\hline 1 & 4.209 & 22.154 & 22.154 \\
2 & 3.654 & 19.232 & 41.387 \\
3 & 2.354 & 12.387 & 53.773 \\
4 & 1.260 & 6.632 & 60.406 \\
\hline
\end{tabular}

Items were arranged into factors based on the size of loading with respect to statistical analysis. The first factor consisted of seven items (peaceful, relax, polite, mild, unhurried, clean and happy) and was named external characteristic factor. The second factor comprised of 
another 7 items (adult, modern, new, active, decisive, clever and fast) that were mostly associated with the factor entitled emotional factor. The third factor was classified with four items (luxurious, difficult, urban and determined) and labeled as Taste and Intention Factor. The last factor was one item so it could be eliminated.

Table V present factors extraction

\begin{tabular}{ll}
\hline & Factor Loading \\
\hline Factor 1: External Characteristic Factor & .755 \\
Peaceful & .751 \\
Relax & .706 \\
Polite & .688 \\
Mild & .682 \\
Unhurried & .681 \\
Clean & .604 \\
Happy & \\
Factor 2: Emotional Factor & .693 \\
Adult & .690 \\
Modern & .637 \\
New & .625 \\
Active & .617 \\
Decisive & .608 \\
Clever & .584 \\
Fast & \\
Factor 3: Taste and Intention Factor & .762 \\
Luxurious & .755 \\
Difficult & .552 \\
Urban & .478 \\
Determined & \\
\hline
\end{tabular}

The result of exploratory factor analysis for students' perception on image of CIT shows that there are 2 keys on decision making toward institutional image; external appearance (external characteristic factor) and affective links (emotional factor and taste and intention). External appearance may refer to brand image. A place branding is basically focused on attractions and location image that might attract events, investors, visitors (e.g. students or professionals), trade and the category of people termed "influencers" (Anholt, 2010). A strong brand image provides the firm with a sustainable competitive advantage that drives loyalty (Harris and de Chernatony, 2001; Hatch and Schultz, 2003). It is commonly known that branding influences on individual's perception and decision making to purchase or choose the product of service. Affective links means emotional factor, including taste and intention which effect psychologically on individuals. The influences of individual's emotion usually express in some way. The taste and intention may be a driven force for the students to choose to study at the suitable institutional education.

\section{Conclusion}

This research investigate the students' perception factor on institutional education image by using exploratory factor analysis. It was found 3 factors regarding both external outlook of the university and emotional - affective image. The paper showed that the external characteristic factor is the most influential factors that affect students' perception which mean the appearance draws an attention to students. This research revealed some traced evidence of student-as- customer concept in education. The students (service receiver) tend to make a decision based on the publicity from school (service provider). Pinkaeo and Speece (2001) mentioned that university education is a high - involvement service in Thailand. High-involvement product and services such as education, mat not have frequent repurchase, but they can have substantial word-of-mouth that is also supported by brand and image.

The influence of brand and image directly affect students' decision to choose where to study. The organizational image is important in a present day. The management leader or executives should be aware of this image as marketing awareness. To be able to be in a strong competitive situation, the universities executives should maintain a well - defined branding and image of its institution. The business tools such as VRIO analysis may also apply to enhance and gain more competitive advantage in the field.

This findings are presented from a certain area therefore further exploration and research is required to determine applicability to other institution.

\section{References}

[1] Al-Rfou Ahmad Nahar (2013). Factors that Influence the Choice of Business Major Evidence from Jordan. Journal of Business and Management. Vol. 8 Issue: 2 pp. 104 - 108

[2] Anholt,S. (2010) Definitions of place branding - working towards a resolution", Place Branding and Public Diplomacy, Vol. 6, pp. 1-10

[3] ASEAN University Network (2016). Guide to AUN - QA assessment at programme level version 3.0. Bangkok, Thailand

[4] Barich H. and Kotler P. (1991). A framework for marketing image management. Sloan Management Review. Vol. 32 pp.94 - 104.

[5] Brown R. and Mazzarol T. (2009). The importance of institutional image to student satisfaction and loyalty within higher education. Higher Education. Vol. 58. pp. 81 - 95.

[6] Carnasciali M., Thompson A. E., Thomas T. J.. (2013) Factors Influencing Students' Choice of Engineering Major at the University of New Haven. Proceeding of 120 th ASEE Annual Conference and Exposition. Atlanta. June 23 - 26, 2016.

[7] Kardes, F.R., Kalyanram, G., Chandrashekaran, M. and Dornoff, R.J. (1993). Brand retrieval, composition, consumer choice, and the pioneering advantage. Journal of Consumer Research, Vol. 20 pp. 62-75.

[8] Keshishian F., Brocavich J. M., Boone Thomas and Pal Somnath. (2010).Motivating Factors Influencing College Students' Choice of Academic Major. American Journal of Pharmaceutical Education. Vol. 74 Issue: 3 Article 46.

[9] Hannover Research (2015). 2016 Trends in Higher Education Marketing, Enrollment, and Technology. Virginia. United State of America.

[10] Harris, F. and de Chernatony, L. (2001). Corporate branding and corporate brand performance, European Journal of Marketing, Vol. 35, pp. 441-456.

[11] Hatch, M.J. and Schultz, M. (2003). Bringing the corporation into corporate branding.

European Journal of Marketing. Vol. 37, pp. 1041-1064

[12] Helgessen O. and Nesset E. (2007). Image, satisfaction and antecedents: Drivers of student loyalty? A case study of Norwegian University College. Corporate Reputation Review. Vol. 10, pp. 38 - 59.

[13] Hemsley - Brown J. and Goonawardan (2007). Brand harmonization in the international higher education market. Journal of Business Research. Vol. 60. pp. 942 - 948.

[14] Hemsey - Brown J., Melewar T. C., Nguyen B. and Wilson E. J. (2016). Exploring brand identity, meaning, image and reputation (BIMIR) in higher education: A special section. Journal of Business Research. Vol. 96. pp. 3019 - 3022.

[15] Herbig P., Milerwicz J. and Golden J. (1994). A model of reputation building and destruction. Journal of Business Research. Vol. 31 pp. 23 31.

[16] MacEachern James-M and D. Yun. (2017).Exploring factors influencing international students' decision to choose a higher education institution: A comparison between Chinese and other students. International Journal of Educational Management, Vol. 31 Issue 3.

[17] Mazzarol Tim and Soutar Geoffrey N., (2002) "'Push-pull” factors influencing international student destination choice", International Journal of Educational Management, Vol. 16 Issue: 2, pp.82-90, doi: $10.1108 / 09513540210418403$

[18] Moogan, Y.J. (2011). Can a higher education institution's marketing strategy improve the student-institution match?. International Journal of 
Educational Management, Vol. 25 pp. 570- 589.

[19] Nguyen N. and LeBlance G. (2001). Image and reputation of higher education institutions in students' retention decisions. The International Journal of Education Management. Vol. 15 Issue 6. pp. 301 - 311

[20] Perez J.P. and Torres E. M. (2016). Evaluation of the organizational image of a university in a higher education institution. Contaduria y Administracion. Vol. 62. pp. 123 - 140.

[21] Pinkaeo, K. and Speece, M. (2001). Country image and expectations toward international programs in business administration among Thai students. Journal of Marketing for Higher Education. Vol. 11 No. 2, pp. 6189.

[22] Plungpongpan J., Tiangsoongnern L. and Speece M. (2016). University social responsibility and brand image of private universities in Bangkok. International Journal of Education Management. Vol. 30 pp $571-591$.
[23] Purolinna P. (2016). University Image and its Effect on Applying Intention; Case: Aalto University School of Business. Master's Thesis. School of Business, Aalto University, Finland.

[24] Saenmueang S. (2011) Factor affecting intention to choose Suranaree University of Technology of the students with high academic performance in lower - northeastern region.

Master Thesis of Suranaree University of Technology, Thailand

[25] Tang L. C., Seng C. (2016). Factors influence students' choice of accounting major in Cambodian universities. Asian Review of Accounting. Vol. 24 Issue: 2, pp.231-251, doi: 10.1108/ ARA-04-2014-0049

[26] Watjatrakul B. (2014). Factors affecting students' intentions to study at university adopting the "student-as-customer" concept. International Journal of Educational Management. Vol. 28. pp.676 - 693.

[27] Yamane, Taro. (1973). Statistics: An Introductory Analysis. Third Edition. New York : Harper and Row Publication. 